\title{
PENGEMBANGAN E-MODULE MATA PELAJARAN BIOLOGI KELAS XI SEMESTER II MATERI SISTEM PERNAPASAN MANUSIA DI SMA NEGERI 1 KARANGAN TRENGGALEK
}

\author{
Vega Selvian Puspridayanti ${ }^{1}$, Agus Wedi ${ }^{2}$, Saida Ulfa ${ }^{3}$ \\ Jurusan Teknologi Pendidikan, Fakultas Ilmu Pendidikan, Universitas Negeri Malang \\ Email: vega.pheng@gmail.com
}

\begin{abstract}
Abstrak
Proses pembelajaran Biologi di SMA Negeri 1 Karangan Trenggalek masih menggunakan metode penyampaian materi secara konvensional dan bahan ajar cetak yang digunakan kurang mampu menyajikan materi yang menggunakan simulasi seperti video, sehingga siswa kurang tertarik dalam mengikuti kegiatan pembelajaran di kelas karena materi yang dipelajari terkesan monoton. Penelitian ini bertujuan untuk mengembangkan media pembelajaran berupa elektronic module yang valid, layak dan efektif digunakan dalam proses pembelajaran. Metode pengembangan yang digunakan adalah model pengembangan William W. Lee dan Diana L. Owens (2004) dengan prosedur pengembangan yang terdiri dari: 1) Analisis (Analysis), 2) Desain (Design), 3) Pengembangan (Development), 4) Implementasi (Implementation), 5) Evaluasi (evaluation). Hasil validasi ahli materi diperoleh 96,25\%, ahli media diperoleh 92,5\%, dan uji coba dilakukan sebanyak tiga kali dengan uji coba perseorangan diperoleh hasil 84,15\%, uji coba kelompok kecil diperoleh hasil91\%, uji coba lapangan diperoleh hasil 91\% dan tes hasil belajar diperoleh 84,21\%. Berdasarkan hasil validasi, uji coba produk dan uji keefektifan membuktikan bahwa e-module termasuk dalam kriteria valid, layak dan efektif digunakan dalam proses kegiatan belajar mengajar
\end{abstract}

Kata kunci :Pengembangan, E-Module, Biologi, Sekolah Menengah Atas

\section{PENDAHULUAN}

Perkembangan teknologi dunia yang semakin berkembang pesat akan mempengaruhi berbagai aspek kehidupan mulai dari politik, ekonomi, sosial, budaya dan pendidikan. Perlu adanya inovasi baru untuk menciptakan proses belajar mengajar yang berkualitas. Pendidikan merupakan usaha manusia untuk membentukkepribadiannya sesuai dengan nilai-nilai yang telah ditentukan di dalam masyarakat (Hasbullah, 2011). Pendidikan merupakan sebuah proses yang dapat membantu siswa mengembangkan kemampuannya dalam kehidupan seharihari. Proses pendidikan diperoleh siswa melalui kegiatan pembelajaran baik secara formal maupun nonformal, sehingga untuk mendapatkan hasil yang baik dari pendidikan harus disertai dengan proses belajar mengajar yang berkualitas pula.

Pembelajaran merupakan proses penggabunggan dari berbagai unsur-unsur seperti manusia, material, fasilitas, dan prosedur yang saling berhubungan satu sama lain dalam mencapai tujuan pembelajaran yang telah ditetapkan (Hamalik, 2004). Proses belajar mengajar yang berkualitas memiliki pengaruh yang sangat signifikan dalam menghasilkan peserta didik yang berkualitas. Pembentukan proses belajar mengajar yang berkualitas, terdapat banyak faktor yang mempengaruhinya seperti pengajar, penggunaan metode pembelajaran yang menarik dan bervariasi, perilaku belajar peserta didik, kondisi dan suasana belajar yang kondusif untuk belajar serta penggunaan media pembelajaran yang tepat. Pembelajaran yang berkualiatas memiliki makna adanya aktivitas pembelajaran yang berlangsung dengan menggunakan waktu dan sumber daya yang relatif sedikit. Pembelajaran dihasilkan untukmenjadi sebuah kegiatan 
yang menarik sehingga mampu meningkatkan minat dan motivasi belajar siswa. Salah satu cara yang dapat digunakan untuk meningkatkan minat dan motivasi siswa adalah dengan menggunakan media pembelajaran dalam proses pembelajaran.

Inovasi dalam media pembelajaran berupa pengembangan multimedia pembelajaran dengan menyatukan berbagai aspek baik gambar, audio, video maupun animasi. Proses pembelajaran dapat berlangsung ketika terjadi komunikasi antara penerima pesan dengan sumber pesan melalui media. Hadirnya media pembelajaran dapat membantu siswa untuk memahami materi yang dipelajari, namun terdapat aspek yang perlu diperhatikan yaitu kesesuaian antara tujuan pembelajaran yang telah ditentukan dengan penyajian multimedia agar mampu memfasilitasi proses pembelajaran.

$$
\text { Dalam proses kegiatan }
$$

pembelajaran, guru merupakan fasilitator sekaligus motivator, dimana guru tidak hanya menyampaikan materi tetapi juga mampu memotivasisiswa bersikap aktif dalam proses pembelajarannya, sehingga siswa mampu mencari sumber belajarnya melalui berbagai media misalnya modul.Menurut Nasution (2003) modul adalah media pembelajaran yang tersusun dalam kesatuan yang bulat dan lengkap yang di dalamnya terdiri dari serangkaian kegiatan pembelajaran yang mampu memberikan hasil belajar yang efektif untuk mencapai tujuan pembelajaran yang ditentukan.

Seiring perkembangan teknologi dalam bidang pendidikan, modul mulai dikembangkan dalam bentuk media pembelajaran berbasis komputer atau berbentuk elektronik yang dinamakan modul elektronik (e-module). Elektronik modul (e-module) merupakan suatu modul berbasis teknologi, informasi dan komunikasi yang sifatnya interatif memudahkan dalam navigasi yang memungkinkan menampilkan audio, video, gambar, ataupun animasi serta dilengkapi dengan tes yang memungkinkan memperoleh feedback atau umpan balik (Suarsana \& Mahayukti, 2013).

Perkembangan teknologi dalam pendidikan seperti inilah yang menjadi dasar pengembangan e-module untuk mata pelajaran Biologi khususnya di Sekolah Menengah Atas (SMA), karena pembelajaran Biologi membutuhkan fasilitas yang memadai. Pemanfaatan multimedia pembelajaran e-module sesuai diterpakan pada pembelajaran Biologi karena pendidikan Biologi diarahkan untuk pembelajaran inkuiri, sehingga siswa memperoleh pengetahuan yang lebih mendalam mengenai alam sekitar (Gusti Ayu \& Nyoman Tika dalam Anggraeni, 2016). Dalam kegiatan pembelajaran yang berkualitas guru tidak hanya menggunakan satu bahan ajar seperti buku cetak ataupun modul cetak, tetapi perlu memanfaatkan penggunaan media pembelajaran di kelas baik secara individual atau klasikal.

Ketika peneliti melakukan observasi awal di SMA Negeri 1 Karangan Trenggalek diperoleh hasil yang berhubungan dengan kondisi belajar siswa diantaranya beberapa siswa masih sering bergurau ketika guru menjelaskan materi secara konvensional serta bahan ajar cetak yang digunakan kurang mampu menyajikan materi yang menggunakan simulasi seperti video, sehingga siswa kurang termotivasi dalam mengikuti kegiatan pembelajaran di kelas karena materi pelajaran terkesan monoton.

Peneliti melakukan wawancara nonformal dengan guru mata pelajaran Biologi kelas 11 di SMA Negeri 1 Karangan Trenggalek. Berdasarkan 
wawancara diperoleh hasil bahwa kegiatan pembelajaran di kelas masih dilaksanakan sepenuhnya oleh guru dengan bantuan bahan ajar cetak berupa buku paket dan media presentasi powerpoint yang sederhana serta materi yang masih abstrak, sedangkan dalam pembelajaran Biologi mengharuskan siswa untuk mampu memahami materi secara konkrit, mengamati maupun melaksanakan percobaan.

Tujuan dari penelitian pengembangan ini adalah mengembangkan bahan ajar berupa elektronik module (emodule) yang valid, layak dan efektif digunakan dalam proses pembelajaran.

\section{METODE PENELITIAN}

Metode yang digunakan dalam penelitian pengembangan ini disesuaikan dengan tahap-tahap Lee dan Owens (2004) yang terdiri sebagai berikut.

Tahap pertama yaitu analisis. Pada tahap analisis ini terdiri dari dua analisis yaitu analisis kebutuhan (need assessment) dan analisis awal akhir (front end analysis). Analisis kebutuhan dilakukan dengan melaksanakan observasi kecil dalam kelas di sekolah yang bersangkutan dengan tujuan untuk mengamati dan menganalisis kebutuhan proses pembelajaran. Analisis awal akhir merupakan proses menganalisa data informasi yang telah diperoleh peneliti dari kegiatan obeservasi dan wawancara untuk dikembangkan ke tahap selanjutnya. Pada tahap awal akhir terbagi menjadi beberapa tahapan yaitu analisis siswa (audiens analysis), analisis teknologi (technology analysis), analisis situasi (situation analysis), analisis tugas (taks analysis), analisis kejadian penting (critical incident analysis), analisis isu (issue analysis), analisis tujuan (objective analysis), analisis media (media analysis), analisis data (extand analysis), dan analisis biaya (cost analysis).

Tahap kedua yaitu desain. Tahap ini merupakan tahapan perencanaan dalam pengembangan sebuah media. Tahap desain terbagi menjadi tiga tahapan jadwal kegiatan (schedule), tim proyek (project team), spesifikasi media (media specification), struktur konten (lesson structure), konfigurasi control (configuration control). Proses pengembangan e-module ini dilaksanakan mulai bulan februari sampai april dan dirancang sendiri oleh pengembang dengan menggunakan software Autoplay Media Studio 8 serta dikombinasikan dengan aplikasi Adobe Reader XI, Adobe Photoshop CS 6, Adobe Premiere Pro CC 2015, CorelDRAW X7, Wondershare Quiz Creator, Format Factory dan Macromedia Flash.

Tahap ketiga yaitu tahap pengembangan. Pada tahap pengembangan ini dilaksanakan proses pengisian materi. Kegiatan pada tahap ini yaitu menentukan komponen penunjang pengembangan, membuat kerangka berupa storyboard, mengembangkan elemen-elemen media, melakukan review dan revisi produk.

Tahap keempat yaitu tahap implementasi. Pada implementasi ini dilakukan penelitian sebanyak tiga kali yaitu penelitian perseorangan, penelitian kelompok kecil dan penelitian lapangan. Tahap implementasi ini diperlukan untuk mengumpulkan data sebagai dasar dalam menetapkan kelayakan produk yang dihasilkan sehingga menunjang ketercapaian tujuan pembelajaran.

Tahap kelima yaitu evaluasi. Tahap ini dilakukan untuk mengetahui apakah produk yang dikembangkan sudah mencapai tujuan yang ditetapkan. Kegiatan pada tahap ini yaitu tujuan (purpose of evaluation), strategi (evaluation strategy), 
rencana (evaluation plan), pengukuran validitas (measure of validity), analisis dan pengumpulan data (collecting and analyzing).

Produk pengembangan berupa elektronik module (e-module) harus diuji tingkat validitasnya untuk mengetahui kualitas hasil pengembangannya. Tingkat validitas elektronik module (e-module) diperoleh berdasarkan hasil angket dari ahli media, ahli materi dan hasil uji coba perseorangan, uji coba kelompok kecil, uji coba lapangan, selain itu dilaksanakan uji keefektifan setelah menggunakan e-module dengan memberikan tes pada siswa. Data yang diperoleh kemudian dianalisis dan digunakan untuk memperbaiki atau merevisi elektronik module (e-module) yang dikembangkan.

Metode pengumpulan data yang digunakan dalam penelitian ini adalah angket tertutup. Angket tertutup adalah angket yang didalamnya terdapat pilhan jawaban dan responden memilih jawaban yang sesuai dengan keinginannya. Angket yang digunakan untuk mengumpulkan data hasil review berasal dari ahli materi, ahli media, uji coba perseorangan, uji coba kelompok kecil dan uji coba lapangan.

Dalam penelitian pengembangan ini digunakan teknik analisis data yaitu data kuantitatif dan data kualitatif. Data kuantitatif diperoleh berdasarkan penilaian elektronik module (e-module) yang berupa skor hasil instrumen angket yang diperoleh dari ahli materi, ahli media dan siswa. Data kualitatif diperoleh berdasarkan saran dan kritik yang diberikan oleh ahli materi, ahli media maupun siswa.

Uji validitas produk diperoleh berdasarkan skor hasil instrumen angket yang diperoleh dari ahli materi, ahli media dan siswa. Data hasil validasi dianalisis menggunakan rumus sebagai berikut.

$$
\mathrm{P}=\frac{\sum x}{\sum x_{i}} \mathrm{x} 100 \%
$$

Keterangan :

$\mathrm{P} \quad=$ Persentase

$\sum \mathrm{X}=$ Jawaban keseluruhan responden

$\sum \mathrm{Xi}=$ Jumlah keseluruhan skor dalam item

$\%=$ Konstanta

Setelah data dianalisis, hasil analisis tersebut dicocokkan dengan kriteria kelayakan penggunaan media.

Kriteria kelayakan penggunaan media terdiri dari lima kategori pilihan sehingga terdiri dari lima kriteria validitas yaitu sebagai berikut.

\begin{tabular}{ll}
\hline Persentase & \multicolumn{1}{c}{ Kualifikasi } \\
\hline $81 \%-100 \%$ & $\begin{array}{l}\text { Sangat valid, sangat layak, dapat } \\
\text { digunakan tanpa perbaikan } \\
\text { Cukup valid, cukup layak, dapat }\end{array}$ \\
& digunakan namun perlu \\
& perbaikan kecil \\
& Kurang valid, kurang layak, \\
& perlu perbaikan besar \\
& Tidak valid, tidak layak, tidak \\
& dapat digunakan \\
& Sangat tidak valid, sangat tidak \\
& layak, tidak dapat digunakan
\end{tabular}

(Sumber: Akbar, 2013 Modifikasi Peneliti)

Uji keefektifan produk diperoleh berdasarkan nilai hasil belajar setelah menggunakan e-module yang diperoleh dari siswa. Data hasil uji keefektifan menggunakan rumus sebagai berikut.

$$
\mathrm{P}=\frac{\text { jumlah siswa yang mencapai KKM }}{\text { jumlah siswa keseluruhan }} \times 100
$$

Keterangan :

$\mathrm{P}=$ Persentase

$100=$ Konstanta

Setelah data dianalisis, hasil analisis tersebut dicocokkan dengan kriteria tingkat keberhasilan 
Kriteria tingkat keberhasilan terdiri dari empat kategori pilihan sehingga terdiri dari empat kriteria keberhasilan yaitu sebagai berikut.

\begin{tabular}{cc}
\hline Persentase & Kualifikasi \\
\hline $80-100$ & Efektif \\
$60-79$ & Cukup Efektif \\
$40-59$ & Kurang Efektif \\
$<40$ & Tidak Efektif \\
\hline
\end{tabular}

(Sumber: Arikunto, 2000)

Keberhasilan belajar dapat dilihat dari Kriteria Ketuntasan Minimum (KKM) secara keseluruhan. Keberhasilan belajar dikatakan tercapai apabila lebih dari setengah jumlah siswa berhasil mencapai Kriteria Ketuntasan Minimum (KKM).

\section{HASIL DAN PEMBAHASAN}

Produk elektronik module (e-module) yang dihasilkan dikemas dalam bentuk Compact Disk (CD). Proses produksi elektronik module (e-module) ini didesain dengan menggunakan software Autoplay Media Studio 8 serta dikombinasikan dengan aplikasi Adobe Reader XI, Adobe Photoshop CS 6, Adobe Premiere Pro CC 2015, CorelDRAW X7, Wondershare Quiz Creator, Format Factory dan Macromedia Flash.
Setelah produk elektronik module (emodule) selesai didesain, maka dilakukan pengecekan untuk memastikan produk berjalan dengan lancar kemudian dilanjutkan pada tahap evaluasi yaitu validasi ahli materi, ahli media dan diuji cobakan siswa. Uji coba siswa dilaksanakan sebanyak tiga kali yaitu uji perseorangan, uji kelompok kecil dan uji lapangan. Selanjutnya dilaksanakan uji keefektifan dengan memberikan tes kepada siswa untuk mengukur kondisi hasil belajar siswa setelah menggunakan e-module.

Produk elektronik module (e-module) divalidasikan kepada ahli materi yaitu Dr. Abdul Gofur, Msi. Instrumen yang digunakan untuk uji coba ahli materi yaitu angket tertutup. Setelah data pada angket diolah maka diperoleh hasil analisis data ahli materi sebesar 96,25\% dan berdasarkan dari kriteria kelayakan penggunaan media maka dapat diinterpretasikan bahwa elektronik module (e-module) yang telah dikembangkan termasuk dalam kategori valid atau layak dan dapat digunakan tanpa perbaikan.

Produk elektronik module (e-module) ini divalidasikan kepada ahli media yaitu Eka Pramono Adi, S.IP, M.Si. Instrumen yang digunakan untuk uji coba ahli materi yaitu angket tertutup. Setelah data pada angket diolah maka diperoleh hasil analisis data ahli media sebesar 92,5\% dan berdasarkan dari kriteria kelayakan penggunaan media maka dapat diinterpretasikan bahwa elektronik module (e-module) yang telah dikembangkan termasuk dalam kategori valid atau layak untuk dimanfaatkan dalam proses pembelajaran.

Setelah produk pengembangan elektronik module (e-module) divalidasi oleh ahli media dan ahli materi serta diperoleh hasil dengan kategori valid atau layak digunakan dalam pembelajaran, 
maka tahap selanjutnya yaitu melakukan uji coba pada siswa. Uji coba yang pertama yaitu uji coba perseorangan yang dilaksanakan oleh tiga siswa kelas XI IPA 4 SMA Negeri 1 Karangan Trenggalek.Berdasarkan hasil uji coba diperoleh hasil analisis sebesar $84,15 \%$ dan berdasarkan dari kriteria kelayakan penggunaan media maka dapat diinterpretasikan bahwa elektronik module (e-module) yang telah dikembangkan termasuk dalamkategori valid atau layak dan dapat digunakan tanpa perbaikan.

Setelah selesai melalui uji coba perseorangan, elektronik module (emodule) yang dikembangkan dalam penelitian ini dilanjutkan dengan tahap uji coba kelompok kecil. Uji coba kelompok kecil dilaksanakan oleh lima siswa kelas XI IPA 4 SMA Negeri 1 Karangan Trenggalek. Berdasarkan hasil uji coba diperoleh hasil analisis sebesar 91\% dan berdasarkan dari kriteria kelayakan penggunaan media maka dapat diinterpretasikan bahwa elektronik module (e-module) yang telah dikembangkan termasuk dalam kategori sangat valid atau sangat layak dan dapat digunakan tanpa perbaikan.

Setelah melaksanakan uji coba perseorangan dan kelompok kecil serta memperoleh hasil dengan kategori valid, maka dilanjutkan dengan uji coba lapangan. Uji coba lapangan dilaksanakan oleh 30 siswa kelas XI IPA 4 SMA Negeri 1 Karangan Trenggalek. Berdasarkan hasil uji coba diperoleh hasil analisis sebesar 91\% dan berdasarkan dari kriteria kelayakan penggunaan media maka dapat diinterpretasikan bahwa elektronik module (e-module) yang telah dikembangkan termasuk dalam kategori valid atau layak dan dapat digunakan tanpa perbaikan.

Setelah melaksanakan validasi pada ahli materi dan ahli media, serta diujicobakan pada siswa, dilakukan uji keefektifan dengan memberikan tes pada siswa. Berdasarkan hasil tes diperoleh hasil analisis sebesar $84,21 \%$ dan berdasarkan dari kriteria tingkat keberhasilan maka dapat diinterpretasikan bahwa elektronik module (e-module) yang telah dikembangkan termasuk dalam kategori efektif.

Sehingga berdasarkan hasil uji coba secara keseluruhan diperoleh hasil bahwa elektronik module (e-module) valid, layak dan efektif digunakan untuk proses pembelajaran.

\section{KESIMPULAN}

Penelitian ini menghasilkan produk pengembangan berupa elektronik modul (e-module) untuk mata pelajaran Biologi materi Sistem Pernapasan Manusia di SMA Negeri 1 Karangan Trenggalek.

Proses pengembangan produk $e$ module ini menggunakan metode penelitian pengembangan William W. Lee \& Diana L. Owens yang terdiri dari lima tahap yaitu analisis (analysis), desain (design), pengembangan (development), implementasi (implementation) dan evaluasi (evaluation).

Berdasarkan hasil validasi dari ahli materi diperoleh hasil analisis data sebesar 96,25\% termasuk dalam kategori valid atau layak dan dapat digunakan tanpa perbaikan, sedangkan hasil validasi dari ahli media diperoleh hasil analisis data sebesar 92,5\% termasuk dalam kategori valid atau layak dan dapat digunakan tanpa perbaikan.

Uji coba produk dilaksanakan sebanyak tiga kali dengan hasil uji coba yaitu 1) Uji coba perseorangan diperoleh hasil analisis sebesar $84,15 \%$ termasuk dalam kategori valid atau layak dan dapat digunakan tanpa perbaikan, 2) Uji coba kelompok kecil diperoleh hasil analisis 
sebesar 91\% termasuk dalam kategori valid atau layak dan dapat digunakan tanpa perbaikan, 3) Uji coba lapangan diperoleh hasil analisis sebesar 91\% termasuk dalam kategori valid atau layak dan dapat digunakan tanpa perbaikan.

Uji keefektifan dilaksanakan dengan memberikan tes hasil belajar pada siswa. Berdasarkan hasil analisis diperoleh data sebesar $84,21 \%$ termasuk dalam kategori efektif.

Saran-saran yang diberikan berhubungan dengan pengembangan $e$ moduledikelompokkan menjadi dua yaitu (1) saran pemanfaatan yang terdiri dari saran sebelum pelaksanaan pembelajaran yang berisi untuk mempersiapkan segala sesuatu yang diperlukan dalam peroses pembelajaran dengan e-module, saran ketika pelaksanaan yang berisi kegiatan pedampingan dan bimbingan kepada responden atau siswa ketika menggunakan e-module, saran setelah pelaksanaan yang berisi memberikan evaluasi setelah proses pelaksanaan pembelajaran dengan $e$ module, (2) pengembangan produk lebih lanjut yang berisi perbaikan tampilan maupun isi dari produk e-module.

\section{DAFTAR PUSTAKA}

Akbar, S. 2013. Instrumen Perangkat Pembelajaran. Bandung: PT Remaja Rosdakarya.

Anggraeni, C. M. 2016. Pengembangan E-Module Mata Pelajaran IPA Kelas IV Semester II Materi Energi dan Penggunaannya di MI Sunan Kalijogo Karang Besuki Malang. Skripsi tidak diterbitkan. Malang: FIP UM

Arikunto, S. 2000. Manajemen Penelitian. Jakarta: PT. Rineka Cipta.

Hamalik, O. 2004. Proses Belajar Mengajar. Jakarta: PT Bumi Aksara.

Hasbullah. 2011. Dasar-Dasar Ilmu Pendidikan. Jakarta: PT RajaGrafindo Persada.

Lee, W.W., \& Owens, D.L. 2004. Multimedia Based Instructional Design: Second Edition. San Francisco: Pfeiffer.

Nasution, S. 2003. Berbagai Pendekatan Dalam Proses Belajar dan Mengajar. Jakarta: PT Bumi Aksara

Suarsana, I. M \& Mahayukti, G. A. 2013. Pengembangan E-Module Berorientasi Pemecahan Masalah untuk Meningkatkan Keterampilan Berpikir Kritis Mahasiswa. JPI (Jurnal Pendidikan Indonesia), 2(2), 266. Dari http://id.portalgaruda.org/?ref=browse \& $\bmod =$ viewarticle $\&$ article $=139023$ 